\title{
Gender, Family, Race, and the Colonial State in Early Nineteenth-Century Jamaica
}

\author{
Aaron Graham | ORCID: 0000-0003-3846-2326 \\ University of Oxford, Oxford, U.K. \\ aaron.graham@history.ox.ac.uk
}

\begin{abstract}
Recent work has emphasized the role of colonial state structures in the construction and enforcement of race and gender in the British Empire from the seventeenth century onward, particularly among people of color. But work on the parallel phenomenon of "Whiteness" has focused on White men rather than White women and children, on elites rather than those below them, and on North America rather than the Caribbean. This article, using the records of a "Clergy Fund" established in Jamaica in 1797 as an insurance scheme for the (White) widows and orphans of clergymen, therefore addresses a gap in this literature by providing a case study of how a colonial state in the Caribbean tried-and failed - to construct and enforce race and gender among White women and children from outside the elite, during a period when White society in the region seemed under threat.
\end{abstract}

\section{Keywords}

Caribbean - Jamaica - gender - race - religion

Recent work on colonial regimes from the seventeenth century onward has placed gender, race, and the family at the center of the colonial state, excavating the ways in which imperial elites attempted to reproduce the European household as a cultural, social, and economic unit, and to police the boundaries between races, classes, and genders. There is now an extensive literature which relates this to the wider debate about the place of Black and White colonial families within an increasingly multicultural British Empire from the seventeenth century onward, which has pointed out not only the mixed effectiveness 
of these state structures but also their long-term consequences for the construction of racial identities. Recent work has begun to explore the parallel phenomenon of "Whiteness," but it has largely focused on the experiences of White men rather than White women and children; on members of the elite such as planters rather than those below it; and on Whites living in North America, despite the central role played by Caribbean colonies in the formation of the cultural and racial attitudes of North American slavery. The survival of records from a "Clergy Fund" in Jamaica in 1797 to support the widows and orphans of White clergymen makes it possible to begin to correct this. As Durba Ghosh has shown in her study of a similar fund in India for soldiers' dependents, such schemes were relatively small parts of the wider colonial state, but in delineating the boundaries of their eligibility they "raised larger concerns about what was required to be a British subject, their rights, and the question of race" (Ghosh 2003b:3). In Jamaica, the Clergy Fund helped to reinforce the symbolic role of White women and children as the virtuous and vulnerable counterpoises to the moral and sexual corruption of Black enslaved women, a process limited only by the underlying weakness of the colonial state and the intervention of greater priorities.

Historiography

By bringing together various studies of "the centrality of white male privilege, marital strategy and concubinage to the establishment and legitimisation of European authority in colonies and outposts across the globe," and the "hybrid forms of local authority that were used to managed everyday social and intimate relations," Kathleen Wilson argued in 2011 for a new view of state formation in Britain and the imperial world in the eighteenth and nineteenth centuries (Wilson 2011:1295-96, 1313-19). Shifting the focus from the orthodox loci of power and governance such as taxation, warfare, and trade, her study of the colonial state in frontiers such as India and Jamaica revealed a common factor, namely that "issues of population, sexual and family regulation, and national belonging loomed large in the dynamics of local governance" (Wilson 2011:1296). Its power was used to impose European norms of gender, race, and class, in particular the restriction of women to defined and limited gender roles focused on domesticity; the creation of strict barriers in sexual relations between different races to prevent mixed-race offspring; and the construction of hierarchies of deference between enslaved and free peoples. ${ }^{1}$ This comple-

1 Bush 1981; Ghosh 2003a; Hardwick, Pearsall \& Wulf 2013; Wulf 2010:238-47. 
ments traditional studies of colonial state formation and state capacity which focus on warfare and taxation and the role of Jamaica, for example, as one of the "colonial sinews of imperial power" in the Caribbean. ${ }^{2}$ The history of the Clergy Fund offers an opportunity to develop this analysis further by examining how the administrative and financial mechanisms, developed in part for warfare, were used to delineate and reinforce the status of an overlooked group within Jamaica - White women and children — as well as a range of other functions.

As has already been noted, in recent years the role of the colonial states in the West Indies in controlling the bodies and status of men and women, both Black and White, free and enslaved, has received considerable attention. Most of this research has focused though on slaves and free people of color; the related efforts of planters to control fertility; reproduction and the family lives of the women caught up in this system; and the social institutions such as prisons, hospitals, and asylums used to try to back up these efforts. ${ }^{3}$ Wideranging gender and racial provisions within the slave codes and discriminatory legislation were aimed at Black women and children, and institutions of the colonial state such as prisons, hospitals, and asylums were used with mixed success to support these efforts to enforce behavior deemed to be appropriate. ${ }^{4}$ "The experience of white women in the English West Indies, however," notes Natalie Zacek, "has remained largely invisible" (Zacek 2009:329). Despite their small numbers - for various demographic reasons, women were always outnumbered by men, in a White community itself always outnumbered by the Black population - they were nevertheless of disproportionate symbolic and cultural importance. By 1800, they were not only expected to meet metropolitan standards of female politeness and sensibility but also to meet an additional criterion of "upholding racial and imperial hierarchies by emblematizing the supposed superiority of white morality and literally reproducing Englishness and whiteness" (Zacek 2009:333). A study of the Clergy Fund demonstrates how the Jamaican state tried to put these expectations into practice and avoid the embarrassment of White women and children failing to meet these standards.

The problem facing colonial regimes, Zacek argues, was that White women also threatened "to subvert these hierarchies by the possibility that, in an allegedly corrupting tropical environment [they] might come to behave in ways

2 Graham 2017; Manning 1966; O'Shaughnessy 2000:34-57, 167-200; Pares 1963; Spurdle 1962.

3 Altink 2007; Burnard 2004:210-40; Bush 1981; Fuentes 2016; Livesay 2018; Mair 2006:41-97, 190-317; Newman 2018; Paugh 2017; S. Turner 2017; Vasconcellos 2015; Walker 2020.

4 Altink 2001; Fryar 2016; Hogarth 2017; M. Jones 2008; Paton 2004, esp. 100-34; Smith 2014:6152. 
inappropriate for [their] race and gender" (Zacek 20o9:333). This tension was greatly magnified under abolitionist pressure after 1800 . British metropolitan opinion had always been at best ambivalent about the unrestrained sexuality of the planter classes, their irregular relations with non-White women, and the production and acknowledgment of mixed-race offspring, but by this period such conduct had become an important part of the abolitionist critique of slavery on the basis that it corrupted the morality of both slaves and slaveowners. ${ }^{5}$ Planters were already concerned about the potential for relationships between White women and Black men to undermine the racial boundaries of slave society but now faced additional pressure to preserve and elevate the status of White women as the guarantors of domestic morality, racial division, and social hierarchy. Daniel Livesay has argued that the tolerance for racial diversity in families was already becoming restricted by this period, with the integrity of the White family now seen as both a reason for and product of moral reform (Livesay 2018:232-397).

The Clergy Fund was thus founded at a moment when the status of White women and children was becoming particularly prominent, and thus an important area for the exercise of political power. Assessing attitudes and expectations of White women and families in the Caribbean though, let alone the extent to which the colonial state was able to regulate and circumscribe their conduct, has been complicated by a lack of material. Zacek, Walker, and others have shown with correspondence, diaries, and other sources how the various patriarchal elements of English common law were incorporated into colonial statutes and regulated the conduct of White women, and several studies have shown how poor relief in particular was employed in Jamaica, Barbados, and South Carolina to control White women outside the elite (Mair 2006:3-35, 101-5, 139-56; Walker 2020, esp. pp. 25-165; Zacek 2010:170-205). By refusing support to White women who had formal or informal relationships with Black men, planters turned this element of the colonial state into "an important and hitherto unheralded part of the gel that united White society." ${ }^{n}$ During the scandal of the Manning divorce in 1741, Jamaican elites used the power of the assembly to punish Elizabeth Manning with social death for her alleged sexual relations with a Black man (Burnard 2002). On the other hand, recent work on the White family in Jamaica suggests that there were also limits on the effectiveness of the colonial state. Daniel Livesay and Christer Petley have shown how the West Indian family still accommodated degrees of racial difference even

5 Barash 199o; Burnard 2006; Bush 1981; Mackie 2006; Mair 2006:3-40, 101-85; Newman 2010; Wilson 2003:129-68; Yeh 2006.

6 Forde-Jones 1998; C. Jones 2007:13-79; Lockley 2005:976; Mair 2006:135-48. 
in the late eighteenth century, and recent work by Walker and others emphasizes that White women could still exercise substantial autonomy within the law as wives, widows, executors, and trustees. ${ }^{7}$ More detailed studies, however, are rare, especially for White women outside the ranks of the elite.

This is due at least in part to a lack of records, since the survival of materials from colonial states in the British West Indies is patchy (Brereton 1998). However, the presence in the Jamaica Archives of records from the Clergy Fund in Jamaica in the early nineteenth century offers a unique opportunity to see how, and how effectively, the colonial state in Jamaica met its ambitions (Anonymous 1841:1-9; Minter 1990:39-42, 126-29). As noted at the start, Ghosh has used the study of a similar fund in the East Indies to draw wider conclusions about how race, gender, and family was delineated by the colonial state, and its complex and even sometimes contradictory priorities, which tended to muffle efforts to use these funds to impose proper standards of conduct (Ghosh 2003b). Eve Rosenhaft also identified very similar dynamics within German widows' funds during the same period, while the Clergy Fund of Jamaica had several other important predecessors in Britain and North America which nevertheless differed greatly in some respects and can help to pick out what was distinctive about the Jamaican institution (Rosenhaft 2004 and 2006). ${ }^{8}$ Although less can be said than one might like about the widows and children themselves, the records of the fund do show clearly enough how they were regarded by the (male) architects of the colonial state in Jamaica, how that state worked to reflect and reinforce those perceptions, and the factors which frustrated or limited the exercise of this power.

\section{$2 \quad$ Foundation, 1797}

The Clergy Fund was established in 1797 by an act of the Jamaican house of assembly to provide pensions for the widows and orphans of clergymen from the Church of England who had died whilst they were in Jamaica. Ten percent of their salaries would be deducted each year and paid into a fund which would provide the pensions, with the whole process being overseen by a Board of Trustees appointed from the island's political and ecclesiastical elite. Widows would receive pensions until they died; boys would receive an allowance until

7 Burnard 1991; Josephs 2015; Livesay 2018:20-232; Pearsall 2003; Petley 2005; Sturtz 1999; Walker 2020 .

8 For earlier funds in Britain and North America, see below. I am not aware of similar schemes elsewhere in the British Caribbean. 
they were 16 years old; and girls until they reached 21 or married.Various aspects were modified in subsequent acts of 1821 and 1845 , but the essentials remained unchanged. It had numerous precedents and was mainly intended to buttress the Church of England in Jamaica. This was the established Church of the island, ministering in principle to a population in 1800 of about 15,00o Whites, 3 3,000 "free people of color," and about 300,000 slaves. ${ }^{9}$ In reality, it was grossly unprepared to meet these demands; faced competition from Moravian, Baptist, and Methodist missionaries; and was especially tarred by its complicity with the slave-owners on the island. There were about 20 parishes on the island by 1800 , each with a rector. Most owned slaves, as domestic servants or as laborers on glebe land attached to the parishes, and most therefore either reluctantly accepted slavery or openly supported it, as in the case of vocal proslavery clerics John Lindsay and George Wilson Bridges. ${ }^{10}$ Though framed as a response to these deep-seated problems, and ostensibly intended to reform the character of the Church of England in Jamaica, the Fund was in fact a manifestation of several other factors and intentions, which limited its impact from the outset.

The Fund was a product firstly of the growing power and ambitions of the Jamaican assembly. By 1800 this was by far the most active colonial legislature in the British Atlantic and was passing a range of acts which were extending its power deeper and deeper into the economy, society, and culture of the island, and with greater efficiency than ever before. ${ }^{11}$ This increase was driven mainly by fiscal and military legislation, which accounted for more than half of total legislative output, but at least a further third covered a growing range of social and economic areas, including religion. Having passed an act in 1748 to regulate clerical livings, for instance, the assembly passed other acts in 1770 and 1773 to encourage ministers to come to the island and to enable local parishes to raise money for providing proper churches, parsonages, and cemeteries. ${ }^{12}$ The Clergy Fund also, secondly, reflected the broader administrative ambitions of the house of assembly in Jamaica. Whereas in Britain the bureaucratic business of running the fiscal-military state fell on the shoulders of the civil service, which was responsible to the Crown rather than Parliament, colonial assemblies in the eighteenth century in both North America and the West Indies

9 Brathwaite 1971:23-25; Dunn 1972:300-34; Minter 1990:11-140, 188-290; M. Turner 1982:314.

10 Dunkley 2011; Glasson 2012, esp. 199-232; Higman 2011; Minter 1990:34-39, 140-6o.

11 Graham 2017; Graham 2018a; Graham 2018b; Manning 1966:127-39.

12 Laws of Jamaica 1802-24, I:337-39 (21 Geo. II c. 6); Laws ofJamaica 1802-24,1802-24, II:9899 (11 Geo. III c. 16) and 131-3 (14 Geo. III c. 13); Minter 1990:23-28. For an example of the critiques that may have given rise to these reforms, see Long 1774, II:234-40. 
took for themselves a wide range of these functions. In Jamaica, matters such as colonial finance, public works, and correspondence with the island agent were all managed through committees of the assembly, and Frederick G. Spurdle has noted how, "in any scheme of consequence to be met out of the public purse, the legislature tended to usurp the power of the executive in carrying it out" (Spurdle 1962:127-46; see also Brathwaite 1971:6-12, 40-59 and Manning 1966:61-73). The context for the Clergy Fund was therefore one in which the assembly and the political elites who controlled it were already asserting their power to direct the fiscal and military structures of the island and could redirect this power to effect a variety of changes in other spheres.

This can be seen by contrasting the structure of the Clergy Fund with its counterparts elsewhere in the British Atlantic. The primary model for a clerical charity was the Corporation of the Sons and Friends of the Clergy in England, which had been chartered by the Crown in 1678 "for relief of the poor widows and children of clergymen" (Best 1964; Cox 1978; Pearce 1904). It was imitated in 1743 by the Scottish Ministers' Widows Fund established by the General Assembly of the Church of Scotland and confirmed by an act of Parliament in 1744, which was copied in turn by the Presbyterian Ministers' Fund in Philadelphia in 1759 based on the "laudable example of the Church of Scotland," and the Corporation for the Relief of Widows and Children of Clergymen in British North America, established in 1768 by Anglican clergy there on the same lines (Brackenridge \& Boyd 1988:7-30; Dunlop 1967 20, 24; Stowe 1934:19-33). In all these cases the initiative came from below, with trustees then petitioning the Crown, Parliament, or colonial assemblies for incorporation, often some years after their initial formation..$^{13}$ By contrast, the Clergy Fund was a top-down creation of the assembly in Jamaica, and therefore a reflection of the strength and activist ambitions of the colonial state that had created it.

However, the Clergy Fund was also, thirdly, created as part of a package of measures intended by the assembly to shore up the slave society and undermine metropolitan abolitionists. Pressure had been building in Britain since the 178 os for the abolition of slavery, or at the very least the ending of the slave trade, and the assembly took an active part in rallying opposition, convening select committees in 1789, 1792, and 1804 and publishing their reports in Britain to bolster anti-abolitionist sentiment. ${ }^{14}$ As noted above, one of the many cri-

13 This also contrasts with the German widows' funds examined by Rosenhaft, which were often created from the top down by German states but relied on voluntary participation (Rosenhaft 2004).

14 Brathwaite 1971:291-93; Fergus 2013:36-51, 95-97; Lambert 2005; Petley 2011; Ragatz 1928: 264-67; Ryden 2009:40-82, 186-215. 
tiques leveled by abolitionists was the disordered and corrupted state of morality and family on the island. ${ }^{5}$ Supporting and regulating the position and status of White clerical women and orphans helped to address such criticisms, not least because clerical families were increasingly seen in the metropole as the definitive models for others. Both Anglicans and Nonconformists expected the wives of clergymen in particular to embody female piety, domesticity, and philanthropy as well as a heightened sense of religious devotion commensurate with a clerical household, with the sons and daughters providing the next generation of clergymen and clerical wives. ${ }^{16}$ The protection of the clerical family therefore gained greater importance, and Davidoff, Hall, and Rosenhaft have all emphasized the leading role that clergymen thus played in developing life insurance schemes in Protestant Europe; "part of the[ir] appeal," Rosenhaft concludes, "may have lain in the fact that they made it possible [for them] not only to imagine but to realize a particular vision of marriage," centered on female domesticity, dependence, innocence, and vulnerability (Rosenhaft 2004:181; Davidoff \& Hall 2002:213-15; C. Hall 2002:233-34). A measure to protect clerical families in Jamaica would therefore help to negate some of the most damaging criticisms by abolitionists about the White family in the West Indies.

The measure was thus highly instrumentalist, since it was restricted to Anglican clerical families and was primarily intended as a "a very great encouragement for clergymen with families to come to the island, and from whom, on every rational principle, might [therefore] be expected the more perfect performance of moral and religious duties and examples." ${ }^{17}$ It was therefore, fourthly, an aspect of a sustained campaign being waged by planters against the Nonconformist missionary groups in Jamaica, whom they blamed for persuading slaves to agitate for abolition or emancipation. ${ }^{18}$ Moravian, Methodist, and Baptist missionaries faced continual attacks, and the house of assembly even passed an outright ban on unlicensed preaching in 1802 aimed at undermining Nonconformist missionaries, though this was disallowed by the Colonial Office in London. Among the accusations leveled against the planters by abolitionists was thus a sustained complaint that they had refused to permit the conversion

\footnotetext{
15 See above. For other-linked - moral critiques, see Petley 2012.

16 Davidoff \& Hall 2002:107-26, 149-92, 346, esp. pp. 123-26; C. Hall 2oo2:91-96, 158, 178; Jacob 2007:157-6o; E. Major 2012; Yamaguchi 2014:13, 20-38, 45-71, 76-100.

17 The National Archives of the United Kingdom (hereafter TNA), CO 140/88, Votes of the House of Assembly (hereafter Votes) 1797, pp. 29, 151-54; Laws of Jamaica 1802-24, III:213-18 (38 Geo. III c. 24); Anonymous 1841:4.

18 Minter 1990:34-39, 209-24; A. Murray 1956:23-30; D. Murray 1965:26-30, 42-6; Petley 2009:69-71, 76-84; M. Turner 1982:3-18, 105-26.
} 
of the Black population, who had been kept in ignorance and sin as a result, and that the White population were themselves both morally and racially corrupted through their lack of religious observance. ${ }^{19}$ The Clergy Fund was part of a wider package of measures intended by the island to meet both of these abolitionist criticisms by centering religious activity in the Church of England at the expense of Nonconformists, while also appearing to work to bolster the standard of its clergy. This was because the Church of England was far more deeply wedded to slavery than other religious denominations, for the reasons stated above, despite the efforts of the abolitionist Beilby Porteus as Bishop of London, and could thus be trusted more than other denominations to minister to the Black population without encouraging them to challenge their status as slaves (Brown 2006:352-64).

The Clergy Fund was therefore part of a wider act passed in 1797 intended to raise the standard of the clergy across the board. Beyond tightening up the powers of individual parishes to raise taxes for the construction or maintenance of churches and parsonages, it consolidated the confusing mixture of stipends and fees paid to clergy by parishes, "[which] are inadequate to the support and maintenance of many of them," and replaced them with a uniform set of fees and a fixed stipend of $\mathrm{J} £ 420$ per year, payable by the assembly out of colonial taxes rather than by the parishes. ${ }^{20}$ "As nothing can be more conducive to the preservation of the morals of the people ... than regular instruction in the principles and doctrines of the Christian religion," the clergy were also now required to set aside a certain amount of time each Sunday to instruct slaves and free people of color in the Anglican faith, with its admirable stress on the legality and morality of slavery and the religious need for a perfect submission to the will of both God and the planter. ${ }^{21}$ Acts of 1799 , 1801, and 1804 consolidated and extended these measures and moved the powers to discipline the island clergy from Porteus as Bishop of London into the hands of an Ecclesiastical Commission, staffed by local commissaries and ostensibly intended for

19 Brown 2006:331-91; A. Porter 2004:64-9o; M. Turner 1982:1-30. In practice, the Nonconformist missionaries were generally at best quietist in their attitudes to slavery, and at worst actively complicit, but the crucial element here is the widespread perception that they were instigating abolitionist sentiments in the minds of their enslaved congregations.

20 Laws of Jamaica 1802-24, III:213-18 (38 Geo. III c. 24). For the importance of the parsonage as a space for the clerical family, see Davidoff \& Hall 2002:123-26 and Yamaguchi 2014:20-38. Throughout this period, $£ 100$ sterling was worth $£_{140}$ in Jamaican currency (JE).

21 Laws of Jamaica 1802-24, III:213-18 (38 Geo. III c. 24). 
"the advancement of moral and ecclesiastical discipline."22 In practice, all these measures essentially turned the Church on the island into an instrument of the colonial state.

The Clergy Fund was therefore the product of several overlapping priorities, where the desire to support clerical widows and orphans and preserve them from poverty was overshadowed by the aim of attracting clergy to the island, itself a cynical ploy to head off criticism from abolitionists and preserve slavery in Jamaica. Once the Fund was in operation, the trustees wrestled frequently with the contradictions this imposed. At no point between 1797 and 1846 were the trustees given enough funds by the legislature, even after it became clear that, like many other similar funds, they had grossly underestimated their outgoings. To preserve clerical families, the trustees were not only forced to cut stipends to a point which almost rendered the Fund moot but also to introduce a bureaucratic infrastructure for policing eligibility which excluded some widows and orphans from relief and potentially allowed them to fall into destitution. The survival of a minute book of the trustees for the years between 1797 and 1846 and a description book drawn up in 1846 for current annuitants makes it possible, despite the abbreviated nature of most entries, to draw several wider conclusions about family, gender, class, and race in the colonial state in Jamaica. ${ }^{23}$ These records suggest that although the legislators had clear ideas about the symbolic — and largely ornamental — position of White women and children in colonial society, which they wanted the colonial state to enforce and reinforce, the multiple incompatible priorities noted above limited its actual impact upon those White clerical families, who could nevertheless exercise a degree of agency in some cases to obtain the allowances to which they felt they were entitled.

22 Laws of Jamaica 1802-24, IV:169; Brathwaite 1971:293-4; Minter 1990:109-12; Laws of Jamaica 1802-24, III:29o-91 (39 Geo. III c. 30); Laws of Jamaica 1802-24, IV:137-41 (41 Geo. III c. 27), and 168-74 (42 Geo. III c. 13); Laws of Jamaica 1802-24, V:9-11 (45 Geo. III c. 23). Minter (1990:112) notes that the new commission likewise failed to raise the standards of clerical life, for similar reasons.

23 Jamaica Archives, Spanish Town, Jamaica (hereafter JA), 5/1/15/8 (Description Book, circa 1846) and 5/1/15/9 (Minutes of the Trustees for the Widows and Orphans of the Clergy, 1797-1846). 
Based on the minute- and the description-books, the island had by 1846 relieved some 35 widows and 88 children, at least 13 of them orphans. ${ }^{24}$ As there were around 20 parishes on the island and a high turnover of incumbents, this suggests that the Fund was not reaching all those clerical families who were potentially eligible. Their personal circumstances varied widely. Widows on average joined the Fund when they were 41 years old, but Emma Dallas had been widowed at 33 and Mary Bunbury Fearon at 55 . Children were 9 years old on average when they entered the Fund, and the average family had 2.3 children, but here too there was variation. Unfortunately, the description book was only sporadically updated as widows and children died, married, or came of age, making it difficult to establish the experience of most pensioners, but the entries suggest that widows spent on average about 26 years on the Fund. Very few notes on children have survived. Had they been regularly removed from the books, as the rules dictated, girls would have spent nearly 13 years on the Fund on average and boys just under 8 years, although it is evident that in some cases these rules were set aside. The books also sometimes included details about the current residence of the dependents. Twelve of the 16 widows in 1846 lived in Britain and the remainder in Jamaica, and all but 8 of the 46 children likewise lived in Britain. These variations exacerbated the problems facing the trustees, primarily the pressure to reduce spending, which had knock-on effects for the stipends they were able to offer pensioners to uphold their status and prevent them from slipping into destitution and debasement.

Between 1800 and 1850 , the size of the Jamaican economy dropped, whereas the overall level of spending remained relatively constant, which led to unremitting pressure to trim all nonvital areas of expenditure such as the Clergy Fund (Eisner 1961:189-99; Graham 2017; D. Hall 1959:40-80). The Fund also seriously underestimated its obligations and failed to maintain a sufficient reserve. The West Indies were notorious for their very high rates of disease and mortality, manifested within White families by high rates of widowhood and remarriage (Burnard 1999; Sheridan 1985:185-221). The exact rates, however, were impossible to quantify. Preliminary studies into mortality were undertaken by military doctors in the 1790 s to attempt to address the high level of wastage among regiments posted to the region, but these were restricted to young men rather than families and were not in general circulation (Buckley 1998:398-402; Sheridan 1985:11-16). As a result, many British and American insurers in this period refused to insure people living in the tropics, or else guessed at the premiums required to cover the uncertainty (Murphy 2010:33-37). The trustees of 
the Fund therefore had nothing to guide them in setting sustainable levels of benefits. In this they were not unusual. Even with the benefits of the latest in actuarial science, in 1743 the Scottish Ministers' Widows Fund likewise underestimated its expenditure and overestimated its income by about 25 percent, and required an amending act from Parliament several years later to set it on a sounder footing (Dow 1992:23-55; Dunlop 1967:1-22; Hare \& Scott, 1992:5676). However, its founders had adopted the principle of fixing initial stipends at a conservative level and allowing any surplus to accumulate for reinvestment and occasional redistribution, whereas in Jamaica the assembly made what was later described as the "grand error" of permitting the trustees to set their own rates and dispose of the entire surplus, without maintaining a reserve. ${ }^{25}$

Within a few years the Fund was therefore under considerable financial pressure. The stipend for widows was originally fixed at $J £_{15}$ O per year, which was less than a third of the J£ 420 paid to clergymen under the 1797 act, but still roughly equivalent to the salaries paid by vestries to hospital or workhouse matrons drawn from the island's White middle class. ${ }^{26}$ This stipend was halved to $J £_{70}$ in 1809 and moved steadily downward thereafter, reaching merely J£ 55 per year in 1830, about the amount a midwife, retailer, or innkeeper from the poor White community might earn. Allowances were therefore generous in relation to the little if anything given to non-White women but barely enough to keep genteel clerical widows from falling into the problematic ranks of the poor Whites. The allowance for children was set initially at the high rate of J£ 5 o per year but then divided into "orphans" and "fatherless" after 1809, and both had halved by $1830 .{ }^{27}$ The trustees thus initially fixed the rates far too high and then had to slash them considerably, which would have placed very considerable financial pressure on the beneficiaries. Admittedly, in some cases, the Clergy Fund was not the only source of income left to widows. Dorothy Little noted in 1833 , for instance, that she received $£_{55}$ per year from the Fund and some $\mathrm{J} £ 8$ o from hiring out her slaves in Jamaica, which gave a modest income. ${ }^{28} \mathrm{On}$ the other hand, Mary Pownall laid a petition before the assembly in November 1821 which stated that her husband had been owed five years of arrears as rector,

25 Anonymous 1841:5; Dunlop 1967. The Corporation of the Sons of the Clergy suffered the same problems as the Clergy Fund, and its stipends were similarly volatile; see Cox 1978:31$48,56-67,90-101,133-37$.

26 JA, 5/1/15/9, "Minutes," pp. 10, 12, 14, 18, 26, 29, 30, 31, 35; Anonymous 1841:5-6, 9-11. For the earnings of White women and their standards of living, see Brathwaite 1971:135-50; Higman 2005:81-84; Mair 2006:137-42.

27 JA, 5/1/15/9, "Minutes," pp. 10, 12, 14, 18, 26, 29, 30, 31, 35; Anonymous 1841, pp. 5-6, 9-11.

28 Draper 2010:105-6. For the options open to middling and poor White women in Jamaica, see Mair 2006:127-40. 
that her own savings were exhausted, "and the petitioner is now left with two children without any other dependence than what may be shared to them out of the Clergy Fund," a total of J£ 105 per year. ${ }^{29}$ These reductions in the stipend would therefore have entailed considerable hardship for dependents and perhaps done little to prevent some of them from falling into the embarrassing destitution which setting up the Fund had ostensibly been intended to avoid. The desire to manage and protect the bodies of Whites in Jamaica was therefore now complicated by the imperatives of financial sustainability. Indeed, the trustees later congratulated themselves for refusing to dip into their growing capital fund to maintain a higher stipend, concluding in 1841 that "nothing but a strict adherence to this principle of accumulation ... would have enabled us to withstand the pressure that fell upon it soon after that time" (Anonymous 1841:5).

This readiness to allow White women to fall into indigence to preserve the financial situation of the fund can also be seen in the gradual narrowing of eligibility by the trustees. In 1806 they resolved to restrict the Fund only to children born during the incumbency of each clergyman, and to lay out money from the Fund to secure the necessary legislation from the assembly, though both efforts in 1807 and 1808 failed. ${ }^{30}$ An amending act in 1821 put its finances on a new footing, and although it relaxed some restrictions by allowing the dependents of clergymen who had paid in for between 10 and 20 years to receive half stipends, it tightened them up elsewhere by reducing the allowances made to wives who had not been resident on the island with their husbands. ${ }^{31}$ A proposal by Reverend Campbell in 1835 to extend the stipend to boys to the age of 23, "where it can be shown ... that the sons of the said clergymen are bona fide prosecuting their studies for the Church," was defeated and withdrawn, showing that the island was unwilling to subsidize the principle noted above of the clerical family as the seedbed for the next generation of clergymen. ${ }^{32}$ From 1808 , trustees also began to demand much greater documentary proof from applicants, including lists of the dependents, then formal certificates of their ages and status, which their clerk was required to keep updated, culminating in an order in 1846 for him to keep formal description- and letter-books. ${ }^{33}$ Payment was made conditional on having correct vouchers, with the enrolment of Mrs. Jenkins and her two daughters in 1827 being deferred until she could

\footnotetext{
29 TNA, CO 140/107, Votes 1821, pp. 75-76, 131; JA, 5/1/15/9, “Minutes," p. 27.

3 JA, 5/1/15/9, "Minutes," pp. 8-9.

31 Laws of Jamaica 1802-24, VII:3O1-3 (1 Geo. IV c. 21).

32 JA, 5/1/15/9, "Minutes," p. 36.

33 JA, 5/1/15/9, "Minutes," pp. 10, 16, 17, 19, 20, 27, 47.
} 
provide them with "proper certificates." ${ }^{4}$ The discretionary authority of the trustees was initially exercised rather generously, with Harriet Burton and her five children being advanced J£ 200 in March 1809 for their passage to Europe, the trustees "taking into consideration the embarrassment and distress of her situation." ${ }^{35}$ This gradually dried up. In 1821, for example, Lizey [sic] Frances Haswell asked for the allowance for her son William to be continued past the age of 16 , since he was incapable of taking care of himself "from the loss of his intellects," but this open-ended commitment was rejected. ${ }^{36}$

Though aiming to maintain the respectability of White clerical families as models of conduct for other Whites, when put to the test the trustees were therefore more concerned to maintain the financial integrity of the Fund than to maintain the position of the White women and children who relied on it. This is not to say that the Fund had no effect whatsoever or that dependents were unable to exercise their own agency to obtain what they were owed. As with the Indian fund analyzed by Ghosh, the elements of contract and mutual obligation that were essential principles of the Fund offered a certain degree of leverage for women determined to obtain what was due to them (Ghosh 2003b). Though the laconic entries in the minute book do not provide much detail about petitioners or their petitions, it is clear that in some cases—such as Harriet Burton or Lizey Haswell—widows could petition the trustees directly. ${ }^{37}$ Some could even go over their heads and appeal to the house of assembly. Bonella Stewart was refused admission to the fund in November 1820 , for instance, and presented a petition to the house two weeks later praying either for admission or relief, though the motion to admit the petition was itself decisively defeated. ${ }^{38}$ She may have then switched the focus of attack to the vestry of St Elizabeth's, where her husband had been rector, since the trustees were forced to address a letter to the parish clerk in 1833 confirming that Stewart was not considered to be eligible for relief. ${ }^{39}$ Even when widows were not able to meet the trustees directly, they may have played an important role securing all of the documentation specified by the trustees, as in the case of Harriet Burton, who dispatched an affidavit from Britain in 1815 which confirmed the age of her son and allowed her to claim the $J £_{5} \mathrm{O}$ in arrears which she

\footnotetext{
34 JA, 5/1/15/9, "Minutes," pp. 16, 17.

35 JA, 5/1/15/9, "Minutes," pp. 12-13.

36 JA, 5/1/15/9, "Minutes," p. 25.

37 JA, 5/1/15/9, "Minutes," pp. 12-13, 25.

38 TNA, CO 140/105, Votes 1820, p. 100; JA, 5/1/15/9, "Minutes," p. 23.

39 JA, 5/1/15/9, "Minutes," p. 35. Unfortunately, there is a gap in the minutes of the Clergy Fund between December 1830 and December 1833 .
} 
was owed..$^{40}$ Indeed, the readiness of families to subvert the aims of the Clergy Fund by insisting on the pensions the assembly had promised them, even when they returned home rather than choosing to remain in Jamaica as exemplars of White domesticity, might be seen as further proof of their agency.

Once again though this agency needs to be contextualized, and, just as the careful intervention in gender, family, class, and race by the assembly was cut across by a range of other concerns, so too was the room for women to exercise their agency over the state moderated by a range of other factors. For example, although some women did petition the trustees or even the assembly directly, most of the surviving examples suggest that they primarily interacted with the trustees through male agents, relatives, or friends. The circumstance of Helen Williams and her four children was brought to the attention of the trustees in 1808 , for instance, by three clergymen, who certified that the family were unprovided-for and worthy of being relieved. ${ }^{41}$ The impracticality of requiring up-to-date certificates from dependents living in Britain was represented to the trustees in 1845 by three men acting as their agents in Jamaica, who noted the expense and inconvenience involved, "to parties who in almost all cases perform their duties gratis." ${ }^{2}$ This does not mean these women had no voice at all. The small detail included in the agents' petition in 1845 that "winter is staring these ladies in the face, and a regular remittance is everything to persons of small means" was probably based on letters which had passed between the women and their agents, and, like the widows' petitions analyzed by Ghosh and Rosenhaft, attempted to secure allowances by playing into cultural expectations of female dependency and male responsibility (Ghosh 20o3b; Rosenhaft 2004; Rosenhaft 2006). It was thus, however, an indirect and muffled voice, which relied upon the intermediation of male agents and trustees.

Moreover, although a general pressure for change came from the determination of widows to assert their rights to support from the Fund, policy was also set by the trustees with reference to other factors such as the financial pressures and eligibility requirements noted above, as well as a growing sense of financial sustainability and intergenerational equity. As soon as it became clear that the capital of the Fund might not be adequate to meet future demands, the trustees took steps to increase its income with an amending act in 1804 requiring contributions to continue even when a living was vacant. ${ }^{43}$ By 1820 , numbers of dependents had increased to such a level that the trustees decided to

\footnotetext{
40 JA, 5/1/15/9, "Minutes," p. 20.

41 JA, 5/1/15/9, "Minutes," pp. 9-10. See also p. 19.

42 JA, 5/1/15/9, "Minutes," pp. 56-7.

43 Laws of Jamaica 1802-24, v:9-11 (45 Geo. III c. 23$)$.
} 
lobby the assembly directly for an amending act, which retrospectively argued that the Fund had never been intended to accumulate indefinitely and that contributions should therefore gradually shift from capital accumulation to the payment of pensions. ${ }^{44}$ The overriding concern was equity. "Some plan should be devised to apportion more equally among the clergy of different periods both the expense of contributing towards the fund and the benefits to be derived from it," the committee reported, so the shift would be tapered over the next thirty years, with the "equitable aim ... to equalise, as far as may be, the allowances to annuitants of different periods, but with a leaning in favour of remote annuitants," in order to leave a margin of error. Stipends therefore continued to fall, as noted above, from J£ 70 for widows in 1821 to $J £_{55}$ by 1830 , when the trustees agreed that although the capital had risen by a quarter from $\mathrm{J} £ 20,434$ to J£26,133, "still, from the large sum overpaid ... last year it is considered advisable that the stipends should remain the same." 45 It was only in December 1836 that the trustees raised their stipends to J£10o for widows, then J£ 140 in December 1837, with proportional increases for children, to prevent them from falling into poverty. 46

The end of slavery on the island in 1834 and the period of "apprenticeship" or indentured service in 1838 had comparatively little impact, and between 1838 and 1846 the economy of Jamaica enjoyed a short Indian summer, as tariff protection enabled planters to sell their sugar at high enough rates to pay generous wages to the free population (Eisner 1961:189-99; D. Hall 1959:40-80). Increased prosperity meant that the trustees of the Clergy Fund were briefly able to raise pensions to support the position of clerical families, putting them back into the ranks of the White middle class, but they also continued to look for ways to trim their expenditure. The board agreed in December 1839, for instance, that the existing acts of 1797,1801 , and 1821 should be consolidated and a bill presented to the house of assembly. ${ }^{47}$ They convened a committee in November 1840 "to enquire and report to this Board the amount of pecuniary aid necessary to enable the trustees of this fund to continue the present rate of annuities without any reduction." ${ }^{48}$ The main pressures came from a combination of the growing clamor among the island's curates to be allowed into the Clergy Fund,

44 TNA, CO 140/105, Votes 1820, pp. 68, 109-10; Laws of Jamaica 1802-24, II:301-3 (1 Geo. IV c. 21); Anonymous 1841:5-11.

JA, 5/1/15/9, "Minutes," p. 34. The growth of the Clergy Fund can be tracked in the Journals and Votes of the house of assembly, and up to 1834 in Anonymous 1841:11. It had reached $\mathrm{J} £_{30,839}$ by 1840 and $£_{27,322}$ sterling, or about $\mathrm{J} £ 44, \mathrm{Ooo}$, by 1865 .

46 JA, 5/1/15/9, "Minutes," pp. 36, 38.

47 JA, 5/1/15/9, "Minutes," pp. 4O-41; Laws of Jamaica 1841:227-28 (3 Vic c. 6o ss. 8-10).

48 JA, 5/1/15/9, "Minutes," pp. 42-45. 
on the one hand, and the rise of actuarial science in Britain and the United States on the other (Minter 1990:23-9, 124-29). The latter promised to set life insurance on a more sustainable basis, and was being introduced into the West Indies in the 1840s through agencies of metropolitan firms and the formation of two local firms, the Barbados Mutual Life Assurance Society in 1840 and the Jamaica Mutual Life Assurance Company in $1844 .{ }^{49}$

Under pressure from curates, the assembly set up a separate fund for them in 1842 and decided to consult two actuaries, including John Finlaison, a government actuary and later the first president of the Institute of Actuaries, about merging them upon an equitable basis. ${ }^{50}$ Finlaison advised against it but also took a broader look at the Clergy Fund itself and, horrified, urged further economies. Stipends had been cut by 10 percent for 1840 but were now reduced even further to J£ 83 by 1846 on his advice, as, "if the present annuitants continue to receive pensions above the mean ... future annuitants will be compelled to put up with allowances proportionably below the due mean, which would be a most apparent hardship."51 Equity remained key and actuarial science now allowed a more exact calculation of how the funds should be distributed across generations, but at the expense of once again reducing the annuities to present recipients by a third. Similarly, whereas formerly it had seemed only fair that rectors retiring after 10 or 15 years should receive a half or full allowance, Finlaison now argued that this was "a most serious and inequitable drain upon the fund," and that instead the Funds should adopt the practice in Britain of buying out those leaving, "after the mode of purchasing assurances adopted by friendly societies when members change their abode."52 This was duly adopted by two separate acts passed in 1844 and 1845 for separate Curates' and Rectors' Funds, which corrected the "great error" of 1797 by setting a fixed stipend for recipients, subject only to the periodic adjustment by the actuary, and "framed upon the most correct calculations which the circumstances of the case will admit, and in such a manner that the interest of all persons having ... claims ... may be secured." ${ }^{53}$ Once again the colonial state sacrificed White widows and orphans to other priorities.

\footnotetext{
49 Alborn 20o9; Karch \& Carter 1997:1-53; Lindo 1994:1-88; Murphy 2010.

5O Anonymous 1841:11-14 and TNA, CO 140/136, Votes 1842, pp. 118-25; Laws of Jamaica 1843: $349-50$ (6 Vic c. 5o).

$51 \quad$ TNA, CO 140/136, Votes 1844, p. 120.

$5^{2} \quad$ TNA, CO 140/136, Votes 1844, p. 12 O.

53 Laws of Jamaica 1844:117-22 (8 Vic. c. 38); Laws of Jamaica 1846:539-45 (9 Vic. c. 39); Finlaison 1866:1, 7-11.
} 
The Clergy Fund therefore produced a number of outcomes, one of which was the creation of the Jamaica Mutual in 1839, whose founders extensively consulted both the trustees and their actuary before the venture was formally incorporated in 1844 (Lindo 1994:25-26, 70-71). Another was a conservative level of stipends, initially due to underfunding and then to ensure longterm sustainability, which resulted in miserly allowances for the widows and orphans of White clergymen (Bailey 1868a; Bailey 1868b; Finlaison 1866:1-17). Although there is no way to tell how far the prospect of being denied relief influenced their behavior, the decision to cut back allowances made it more likely that these White women and children would fall into poverty and destitution, and also reduced the leverage that the colonial state was able, as in the case of poor relief for poor White women, to exercise in order to promote and reward certain patterns of conduct. Its role in delineating and then reinforcing the position of White women and children on the island was therefore limited. However, the efforts of widows to claim the pensions to which they argued they were entitled help to shed light on the precarious existence of White women below the ranks of the planter elite, and the limited opportunities for agency open to them. More significantly, as an institutional embodiment of the cultural attitudes and assumptions then circulating on the island about the appropriate behavior and conduct of White women and children and families, particularly when they were from clerical families, the Clergy Fund offers an important insight into those views and attitudes. It shows that White women and children were expected to act as exemplars of familial domesticity and virtue and a counterpoint to the disordered moral and sexual corruption of free women of color. Most importantly, however, they were expected to act in an instrumentalist way as the tools of planter interests, to be deployed as a rhetorical answer to abolitionist critiques and then sacrificed as necessary to the more urgent priorities of financial imperatives. Both groups were victims in different ways, and to very different extents, of a colonial state organized and run by, with, and for the White male planters who dominated its politics.

\section{Acknowledgments}

I am grateful to Trevor Burnard, Daniel Livesay, Anne Hanley, and the two anonymous reviewers of this article for their comments and advice. The research was funded by a British Academy Postdoctoral Fellowship, and the arti- 
cle written during a Leverhulme Early Career Fellowship, and I am likewise grateful to both for their financial support.

\section{References}

Alborn, Timothy, 2009. Regulated Lives: Life Insurance and British Society, 1800-1914. Toronto ON: University of Toronto Press.

Altink, Henrice, 2001. Slavery by Another Name: Apprenticed Women in Jamaican Workhouses in the Period 1834-81. Social History 26(1):40-59.

Altink, Henrice, 2007. Representations of Slave Women in Discourses on Slavery and Abolition, $1780-1838$. London: Routledge.

Anonymous, 1841. A Brief Notice of the Rise, Progress and Present State of the Jamaica Clergy Fund. Kingston: n.p.

Bailey, Arthur H., 1868a. Rectors' and Island Curates' Fund of Jamaica:Letter on the Question of Compensation. London: n.p.

Bailey, Arthur H., 1868b. Report on the Rectors' and Island Curates' Funds, Jamaica. Ipswich, U.K.: n.p.

Barash, Carol, 199o. The Character of Difference: The Creole Woman as Cultural Mediator in Narratives About Jamaica. Eighteenth Century Studies 23(4):406-24.

Best, Geoffrey, 1964. Temporal Pillars: Queen Anne's Bounty, the Ecclesiastical Commissioners, and the Church of England. Cambridge: Cambridge University Press.

Brackenridge, R. Douglas \& Lois A. Boyd, 1988. Presbyterians and Pensions: The Roots and Growth of Pensions in the Presbyterian Church, USA. Louisville KY: Westminster John Knox Press.

Brathwaite, Kamau, 1971. The Development of Creole Society in Jamaica, 1770-1820. Oxford: Oxford University Press.

Brereton, Bridget, 1998. Gendered Testimonies: Autobiographies, Diaries and Letters by Women as Sources for Caribbean History. Feminist Review 59(1):143-63.

Brown, Christopher, 2006. Moral Capital: Foundations of British Abolitionism. Chapel Hill: University of North Carolina Press for the Omohundro Institute of Early American History and Culture.

Buckley, Roger N., 1998. The British Army in the West Indies: Society and the Military in the Revolutionary Age. Gainesville: University Press of Florida.

Burnard, Trevor G., 1991. Inheritance and Independence: Women's Status in Early Colonial Jamaica. William and Mary Quarterly 48(1):93-114.

Burnard, Trevor G., 1999. "The Countrie Continues Sicklie”: White Mortality in Jamaica, 1655-1780. Social History of Medicine 12(1):45-72.

Burnard, Trevor G., 2002. “A Matron in Rank, a Prostitute in Manners ...”: The Manning Divorce of 1741 and Class, Race, Gender and the Law in Eighteenth Century Jamaica. 
In Verene Shepherd (ed.), Working out Slavery, Pricing Freedom: Perspectives from the Caribbean, Africa and the African Diaspora. London: Palgrave Macmillan, pp. 133-52. Burnard, Trevor G., 2004. Mastery, Tyranny, and Desire: Thomas Thistlewood and His Slaves in the Anglo-Jamaican World. Kingston: University of the West Indies Press.

Burnard, Trevor G., 20o6. "Rioting in Goatish Embraces": Marriage and Improvement in Early British Jamaica. The History of the Family 11(4):185-97.

Bush, Barbara, 1981. White "Ladies," Coloured "Favourites" and Black "Wenches": Some Considerations on Sex, Race and Class Factors in Social Relations in White Creole Society in the British Caribbean. Slavery \& Abolition 2(3):245-62.

Cox, Nicholas, 1978. Bridging the Gap: A History of the Corporation of the Sons of the Clergy over 300 Years, 1655-1978. Oxford: Oxford University Press.

Davidoff, Leonore \& Catherine Hall, 2002. Family Fortunes: Men and Women of the English Middle Class, 1780-1850. London: Routledge.

Dow, James Bremner, 1992. Early Actuarial Work in Eighteenth-Century Scotland. In A. Ian Dunlop (ed.), The Scottish Ministers' Widows' Fund, 1743-1993. Edinburgh: St Andrew Press, pp. 23-55.

Draper, Nicholas, 2010. The Price of Emancipation: Slave-Ownership, Compensation and British Society at the End of Slavery. Cambridge: Cambridge University Press.

Dunkley, D.A., 2013. Agency of the Enslaved:Jamaica and the Culture of Freedom in the Atlantic World. Lanham MD: Lexington Books.

Dunlop, A. Ian, 1967. Provision for Ministers' Widows in Scotland-Eighteenth Century. In A. Ian Dunlop (ed.), The Scottish Ministers' Widows' Fund, 1743-1993. Edinburgh: St Andrew Press, pp. 1-22.

Dunn, Richard S., 1972. Sugar and Slaves: The Rise of the Planter Class in the English West Indies, 1624-1713. Chapel Hill: University of North Carolina Press.

Eisner, Gisela, 1961. Jamaica, 1830-1930: A Study in Economic Growth. Manchester, U.K.: Manchester University Press.

Fergus, Claudius K., 2013. Revolutionary Emancipation: Slavery and Abolitionism in the British West Indies. Baton Rouge: Louisiana State University Press.

Finlaison, Alexander Glen, 1866. Report on the Jamaica Rectors' Fund, with Annuity Tables. Kingston: printed by George Henderson.

Forde-Jones, Cecily, 1998. Mapping Racial Boundaries: Gender, Race, and Poor Relief in Barbadian Plantation Society. Journal of Women's History 10(3):9-31.

Fryar, Christienna D., 2016. Imperfect Models: The Kingston Lunatic Asylum Scandal and the Problem of Postemancipation Imperialism. Journal of British Studies 55(4):709-27.

Fuentes, Marisa J., 2016. Dispossessed Lives: Enslaved Women, Violence, and the Archive. Philadelphia: University of Pennsylvania Press.

Ghosh, Durba, 2003a. Gender and Colonialism: Expansion or Marginalization? Historical Journal 47(3):737-55. 
Ghosh, Durba, 2003b. Making and Un-Making Loyal Subjects: Pensioning Widows and Educating Orphans in Early Colonial India. Journal of Imperial and Commonwealth History 31(1):1-28.

Glasson, Travis, 2012. Mastering Christianity: Missionary Anglicanism and Slavery in the Atlantic World. Oxford: Oxford University Press.

Graham, Aaron, 2017. The Colonial Sinews of Imperial Power: The Political Economy of Jamaican Taxation, 1768-1838. Journal of Imperial and Commonwealth History 45(2):188-209.

Graham, Aaron, 2018a. Jamaican Legislation and the Transatlantic Constitution, 16641839. Historical Journal 61(2):327-55.

Graham, Aaron, 2018b. Legislatures, Legislation and Legislating in the British Atlantic, 1692-180o. Parliamentary History 37(3):369-88.

Hall, Catherine, 2002. Civilising Subjects: Colony and Metropole in the English Imaginations, 1830-1867. Chicago: University of Chicago Press.

Hall, Douglas, 1959. Free Jamaica 1838-1865: An Economic History. New Haven CT: Yale University Press.

Hardwick, Julie, Sarah M.S. Pearsall \& Karin Wulf, 2013. Introduction: Centring Families in Atlantic Histories. William and Mary Quarterly 70(2):205-24.

Hare, David J.P. \& William F. Scott, 1992. The Scottish Ministers' Widows' Fund of 1744. In A. Ian Dunlop (ed.), The Scottish Ministers' Widows' Fund, 1743-1993. Edinburgh: St Andrew Press, pp. 56-76.

Higman, B.W., 2005. Plantation Jamaica 1750-1850: Capital and Control in a Colonial Economy. Kingston: University of the West Indies Press.

Higman, B.W., 2011. Proslavery Priest: The Atlantic World of John Lindsay, 1729-1788. Kingston: University of the West Indies Press.

Hogarth, Rana, 2017. Charity and Terror in Eighteenth-Century Jamaica: The Kingston Hospital and Asylum for Deserted "Negroes." African and Black Diaspora: An International Journal $10(3): 281-98$.

Jacob, W.M., 2007. The Clerical Profession in the Long Eighteenth Century, 1680-1840. Oxford: Oxford University Press.

Jones, Cecily, 2007. Engendering Whiteness: White Women and Colonialism in Barbados and North Carolina, 1627-1865. Manchester, U.K.: Manchester University Press.

Jones, Margaret, 2008. The Most Cruel and Revolting Crimes: The Treatment of the Mentally Ill in Mid-Nineteenth-Century Jamaica. Journal of Caribbean History 42(2):290-309.

Josephs, Aleric, 2015. Jamaica Planter Women and the Challenges of Plantation Management. Journal of Caribbean History 49(1):1-31.

Karch, Cecilia \& Henderson Carter, 1997. The Rise of the Phoenix: The Barbados Mutual Life Assurance Society in Caribbean Economy and Society, 1840-1990. Kingston: University of the West Indies Press. 
Lambert, David, 2005. The Counter-Revolutionary Atlantic: White West Indian Petitions and Proslavery Networks. Social \& Cultural Geography 6(3):4O5-2O.

Laws of Jamaica, 1802-24. The Laws of Jamaica, 1802-24. Vols. I, II, III, IV, V, and VII. St Jago de la Vega, Jamaica: n.p. [7 vols.]

Laws of Jamaica, 1841. The Laws of Jamaica Passed in the Third Year of the Reign of Queen Victoria, 1841. Spanish Town, Jamaica: n.p.

Laws of Jamaica, 1843. The Laws of Jamaica Passed in the Sixth Year of the Reign of Queen Victoria, 1843. Spanish Town, Jamaica: n.p.

Laws ofJamaica, 1844. The Laws ofJamaica Passed in the Eighth Year of the Reign of Queen Victoria, 1844. Spanish Town, Jamaica: n.p.

Laws of Jamaica, 1846. The Laws ofJamaica Passed in the Ninth Year of the Reign of Queen Victoria, 1846. Spanish Town, Jamaica: n.p.

Lindo, Donald, 1994. Time Tells Our Story: The History of the Jamaica Mutual Life Assurance Society, 1844-1994. Kingston: University of the West Indies Press.

Livesay, Daniel, 2018. Children of Uncertain Fortune: Mixed-Race Jamaicans in Britain and the Atlantic Family, 1733-1833. Chapel Hill: University of North Carolina Press.

Lockley, Tim, 2005. Rural Poor Relief in Colonial South Carolina. Historical Journal 48(4):955-76.

Long, Edward, 1774. The History ofJamaica. London: printed for T. Lowndes.

Mackie, Erin, 2006. Jamaican Ladies and Tropical Charms. Ariel: A Review of International English Literature 37(2-3):189-220.

Mair, Lucille Mathurin, 2006. A Historical Study of Women in Jamaica, 1655-1844. Kingston: University of the West Indies Press.

Major, Emma, 2012. Madam Britannia: Women, Church, and Nation 1712-1812. Oxford: Oxford University Press.

Manning, Helen Taft, 1966. British Colonial Government after the American Revolution, 1782-1820. Hamden CN: Archon Books.

Minter, R.A., 1990. Episcopacy without Episcopate: The Church of England in Jamaica before 1824. Upton-on-Severn, U.K.: Self-Publishing Association.

Murphy, Sharon A., 2010. Investing in Life: Insurance in Antebellum America. Baltimore MD: Johns Hopkins University Press.

Murray, Alexander L., 1956. The Constitutional Development of Jamaica, 1774-1815. Unpublished Ph.D. thesis, University of London.

Murray, D.J., 1965. The West Indies and the Development of Colonial Government, 18011834. Oxford: Oxford University Press.

Newman, Brooke N., 2010. Gender, Sexuality and the Formation of Racial Identities in the Eighteen-Century Anglo-Caribbean World. Gender \& History 22(3):585-602.

Newman, Brooke N., 2018. A Dark Inheritance: Blood, Race, and Sex in Colonial Jamaica. New Haven CT: Yale University Press. 
O'Shaughnessy, Andrew, 2000. An Empire Divided: The American Revolutionary and the British Caribbean. Philadelphia: University of Pennsylvania Press.

Pares, Richard, 1963. War and Trade in the West Indies, 1739-1763. London: Frank Cass. Paton, Diana, 2004. No Bond but the Law: Punishment, Race, and Gender in Jamaican State Formation, 1780-1870. Durham: University of North Carolina Press.

Paugh, Katherine, 2017. The Politics of Reproduction: Race, Medicine and Fertility in the Age of Abolition. Oxford: Oxford University Press.

Pearce, Ernest Harold, 1904. The Sons of the Clergy, 1655-1904. London: John Murray.

Pearsall, Sarah M.S., 2003. “The Late Flagrant Instance of Depravity in My Family”: The Story of an Anglo-Jamaican Cuckold. William and Mary Quarterly 6o(3):549-82.

Petley, Christer, 2005. "Legitimacy" and Social Boundaries: Free People of Colour and the Social Order in Jamaican Slave Society. Social History 3o(4):481-98.

Petley, Christer, 2009. Slaveholders in Jamaica: Colonial Society and Culture During the Era of Abolition. London: Pickering \& Chatto.

Petley, Christer, 2011. "Devoted Islands" and "That Madman Wilberforce": British Proslavery Patriotism During the Age of Abolition. Journal of Imperial and Commonwealth History 39(3):393-415.

Petley, Christer, 2012. Gluttony, Excess, and the Fall of the Planter Class in the British Caribbean. Atlantic Studies 9(1):85-106.

Porter, Andrew, 2004. Religion versus Empire? British Protestant Missionaries and Overseas Expansion, 1700-1914. Manchester, U.K.: Manchester University Press.

Ragatz, Lowell J., 1928. The Fall of the Planter Class in the British Caribbean, 1763-1833: A Study in Social and Economic History. New York and London: The Century Company. Rosenhaft, Eve, 2004. Did Women Invent Life Insurance?: Widows and the Demand for Financial Services in Eighteenth Century Germany. In David R. Green \& Alastair Owens (eds.), Family Welfare: Gender, Property and Inheritance since the Seventeenth Century. Westport CT: Praeger Publishers, pp. 163-94.

Rosenhaft, Eve, 20o6. "But the Heart Must Speak for the Widows": The Origins of Life Insurance in Germany and the Gender Implications of Actuarial Science. In Ulrich Gleixner \& Marion W. Gray (eds.), Gender in Transition: Discourse and Practice in German-Speaking Europe, 1750-1830. Ann Arbor: University of Michigan Press pp. 90-113.

Ryden, David, 2009. West Indian Slavery and British Abolition, 1783-1807. Cambridge: Cambridge University Press.

Sheridan, Richard B., 1985. Doctors and Slaves: A Medical and Demographic History of Slavery in the British West Indies, 1680-1834. Cambridge: Cambridge University Press.

Smith, Leonard D., 2014. Insanity, Race and Colonialism: Managing Mental Disorder in the Post-Emancipation British Caribbean, 1838-1914. Basingstoke, U.K.: Palgrave Macmillan.

Spurdle, Frederick G., 1962. Early West Indian Government: Showing the Progress of 
Government in Barbados, Jamaica and the Leeward Islands, 166o-1783. Palmerston North, New Zealand. [Published by author.]

Stowe, Walter Herbert, 1934. The Corporation for the Relief of Widows and Children of Clergymen. Historical Magazine of the Protestant Episcopal Church 3(1):19-33.

Sturtz, Linda L., 1999. The "Dimduke" and the Duchess of Chandos: Gender and Power in Jamaican Plantation Management - a Case Study or, a Different Story of "a Man [and His Wife] from a Place Called Hope." Revista/Review Interamericana 29:1-15.

Turner, Mary, 1982. Slaves and Missionaries: The Disintegration ofJamaican Slave Society, 1787-1834. Urbana: University of Illinois Press.

Turner, Sasha, 2017. Contested Bodies: Pregnancy, Childrearing and Slavery in Jamaica. Philadelphia: University of Pennsylvania Press.

Vasconcellos, Colleen A., 2015. Slavery, Childhood, and Abolition in Jamaica, 1788-1838. Athens: University of Georgia Press.

Walker, Christine, 2020. Jamaica Ladies: Female Slaveholders and the Creation of Britain's Atlantic Empire. Chapel Hill: University of North Carolina Press.

Wilson, Kathleen, 2003. The Island Race: Englishness, Empire, and Gender in the Eighteenth Century. London: Routledge.

Wilson, Kathleen, 2011. Rethinking the Colonial State: Family, Gender and Governmentality in Eighteenth-Century British Frontiers. American Historical Review 116(5): 1294-1322.

Wulf, Karin, 2010. Women and Families in Early (North) America and the Wider (Atlantic) World. History Compass 8(3):238-47.

Yamaguchi, Midori, 2014. Daughters of the Anglican Clergy: Religion, Gender and Identity in Victorian England. London: Palgrave.

Yeh, Sarah E., 2006. "A Sink of All Filthiness": Gender, Family and Identity in the British Atlantic, 1688-1763. The Historian 68(1):66-88.

Zacek, Natalie, 20o9. Searching for the Invisible Woman: The Evolution of White Women's Experience in Britain's West Indian Colonies. History Compass 7(1):32941.

Zacek, Natalie, 2010. Settler Society in the English Leeward Islands, 1670-1776. Cambridge: Cambridge University Press. 